\title{
Peranan Slik (Sistem Layanan Informasi Keuangan) Pada Pt. Bank Pembangunan Jawa Barat Dan Banten Kantor Cabang Pembantu Jalancagak
}

\author{
Asep Sumarna ${ }^{1}$ \\ Dinas Informasi dan Komunikasi Kabupaten Subang \\ asepsumarna1968@yahoo.com
}

Ade Suparman ${ }^{2}$

FIA Universitas Subang suparmanade09@gmail.com

\begin{abstract}
Absrak
Salah satu lembaga keuangan yang melayani masalah keuangan masyarakat yaitu PT. Bank Pembangunan Jawa Barat Dan Banten Kantor Cabang Pembantu Jalancagak berdasarkan data yang di peroleh terdapat beberapa kegiatan yang dilakukan PT. Bank Pembangunan Jawa Barat Dan Banten Kantor Cabang Pembantu Jalancagak yaitu menghimpun dana dan penyaluran kredit Peran bank dalam penyaluran kredit memang tidak bisa dipungkiri lagi bahwa merupakan usaha yang banyak menghasilkan keuntungan atau return yang tinggi. Dalam hal ini Otoritas Jasa Keuangan atau yang biasa di sebut OJK selaku lembaga yang mempunyai peran mengawasi seluruh kegiatan lembaga keuangan yang ada di Indonesia meluncurkan sebuah sistem yang berbentuk aplikasi yang dinamakan dengan SLIK atau kepanjangan dari (Sistem Layanan Informasi Keuangan) yang diluncurkan dan digunakan secara meluas pada tanggal 1 januari 2018 untuk membantu pengawasan terhadap kreditur dan debitur dan dapat digunakan untuk bertukar informasi.
\end{abstract}

Kata Kunci : Peran, SLIK (Sistem Layanan Informasi Keuangan)

\section{Abstract}

One of the financial institutions that serves the public financial problems, namely PT. West Java and Banten Development Bank Jalancagak Sub-Branch Office based on the data obtained there are several activities carried out by PT. West Java and Banten Development Bank Jalancagak Sub-Branch Office is to raise funds and credit distribution The role of banks in lending is indeed undeniable that it is a business that generates high profits or returns. In this case the Financial Services Authority or commonly called OJK as an institution that has the role of overseeing all activities of financial institutions in Indonesia launches a system in the form of an application called SLIK or stands for (Financial Information Service System) 
which is launched and used extends on January 1, 2018 to help supervise creditors and debtors and can be used to exchange information.

Keywords: Role, SLIK (Financial Information Service System)

\section{Pendahuluan}

Pada umumnya lembaga keuangan melahirkan pengaruh positif bagi perekonomian disuatu Negara tidak terkecuali bagi Indonesia, semua itu dapat dilihat dari semakin berkembangnya dunia bisnis di Indonesia. Bank sebagai salah satu lembaga keuangan yang ikut berperan besar dalam perkembangan perekonomian di Indonesia berupaya membantu para pelaku bisnis dalam hal penyediaan dana.

Bank dalam bahasa Itali adalah banca yang berarti "bangku" (Parker, 2009:1) sedangkan pengertian Bank menurut UU No. 7 Tahun 1992 sebagai mana diubah dengan UU No. 10 Tahun 1998 tentang perbankan adalah "Badan usaha yang menghimpun dana dari masyarakat dalam bentuk simpanan dan menyalurkan kepada masyarakat dalam bentuk kredit dan atau bentuk-bentuk lainnya dalam rangka meningkatkan taraf hidup rakyat banyak", dengan kata lain bank mempunyai fungsi sebagai Intermediation Financial. Bank sebagai perantara keuangan berusaha untuk menjalankan kegiatan operasional dengan prinsip kehatihatian dalam mengelola bisnisnya sebagai upaya untuk membangun dan menjaga kepercayaan masyarakat.

Masyarakat memberikan kepercayaan penuh kepada pihak bank bahwa danayang ditanamkan aman dan dapat diambil sewaktu-waktu jika dana tersebut diperlukan. Demikian pula dengan pihak bank dalam pemberiaan kredit, pihak bank menaruh kepercayaan kepada masyarakat yang menerima fasilitas kredit, sehingga kredit dapat kembali dengan tepat waktu. Walau dalam pemberiaan kredit akan menimbulkan risiko bagi bank, namun kredit merupakan kegiatan usaha perbankan yang sangat diandalkan. Memang tidak bisa dipungkiri lagi bahwa penyaluran kredi merupakan usaha yang banyak menghasilkan keuntungan atau return yang tinggi tetapi dengan diiringi tingkat risiko (kredit macet) yang tinggi pula yang timbul dari penyaluran kreditnya. Kegagalan pembayaran pinjaman (kredit macet) biasanya Terjadi diakibatkan karena modal yang dipinjam digunakan untuk tujuan yang berbeda misalnya tujuan awal adalah untuk usaha tetapi nanti modalnya digunakan untuk keperluan lain. Sama halnya dengan Bank Umum PT. Bank pembangunan Daerah Jawa Barat Dan Banten atau kita lebuh mengenalnya dengan "BJB" Merupakan bank BUMD milik pemerintah provinsi Jawa Barat Dan banten yaitu lembaga keuangan di Indonesia yang mempunyai peranan penting dalam perekonomian Indonesia terutama dalam mendorong perkembangan ekonomi mampu bertahan ditengah krisis yang melanda Indonesia pada tahun 1997 tidak lepas dari peran PT. Bank Pembangunan Jawa Barat Dan Banten yang berorientasi di sektor pemberian krdit, Sehingga PT. Bank Pembangunan Jawa Barat Dan Banten juga membutuhkan manajemen yang baik dalam pengelolaan usahanya. 
PT. Bank Pembangunan Jawa Barat Dan Banten Kantor Cabang Pembantu Jalancagak berupaya memberikan fasilitas kredit dengan bunga ringan, Proses cepat dan persyaratan mudah. Upaya pemberian kredit tersebut diperlukan cepat dan tepat juga. Sehingga kredit yang disalurkan tepat sasaran dan sesuai dengan prosedur dan kebijakan yang ada pada PT. Bank Pembangunan Jawa Barat Dan Banten Kantor Cabang Pembantu Jalancagak. Otoritas jasa keuangan atau yang biasa di singkat "OJK" sebagai lembaga yang mengawasi seluruh lembaga keuangan yang ada di Indonesia meluncurkan sebuah sistem yang bernama SLIK. SLIK merupakan sistem untuk membantu pertukan informasi yang berguna dan dibutuhkan oleh PT. Bank Pembangunan Jawa Barat Dan Banten Kantor Cabang Pembantu Jalancagak dan Lembaga keuangan Bank lainnya .

\section{Kerangka Teori}

\section{a. Pengertian Bank}

Menurut Undang-Undang RI No 10 Tahun 1998 tanggal 10 November 1998 tentang perbankan, yang dimaksud dengan BANK adalah "badan usaha yang menghimpun dana dari masyarakat dalam bentuk simpanan dan menyalurkannya kepada masyarakat dalam bentuk kredit dan atau bentuk-bentuk lainnyadalam rangka meningkatkan taraf hidup rakyat banyak". Menurut Dendawijaya (2009:14) "Bank adalah suatu badan usaha yang tugas utamanya sebagai lembaga perantara keuangan (financial intermediaries), yang menyalurkan dana dari pihak yang berkelebihan dana (deficit unit) pada waktu yang ditentukan". Menurut Kasmir (2010:25) Dalam pembicaraan sehari-hari, bank dikenal sebagai lembaga keuangan yang kegiatan utamanya menerima simpanan giro, tabungan dan deposito. Kemudian bank juga dikenal sebagai tempat untuk meminjam uang (kredit) bagi masyarakat yang membutuhkannya. Disamping itu, bank juga dikenal sebagai tempat untuk menukar uang, memindahkan uang atau menerima segala macam bentuk pembayaran dan setoran seperti pembayaran listrik, telepon ,air ,pajak, uang kuliah, dan pembayaran lainnya. Kasmir (2012:33), kegiatan masing-masing jenis bank dilihat dari segi fungsinya adalah sebagai berikut:

1. Kegiatan Bank Umum Kegiatan bank umum secara lengkap meliputi kegiatan sebagai berikut:

a) Menghimpun Dana (Funding) Kegiatan menghimpun dana merupakan kegiatan membeli dana dari masyarakat. Kegiatan ini dikenal juga dengan kegiatan funding. Kegiatan membeli dana dapat dilakukan dengan cara menawarkan berbagai jenis simpanan. Simpanan sering disebut dengan nama rekening atau account. Jenisjenis simpanan yang ada diantaranya simpanan giro, tabungan, dan deposito.

b) Menyaluran Dana (Lending)Menyalurkan dana merupakan kegiatan menjual dana yang berhasil dihimpun dari masyarakat. Kegiatan ini dikenal dengan nama kegiatan Lending. Penyaluran dana yang dilakukan oleh bank dilakukan melalui pemberian pinjaman yang dalam masyarakat lebih dikenal dengan nama kredit. Kredit yang diberikan 
oleh bank terdiri dari beragam jenis, tergantung dari kemampuan bank yang menyalurkannya. Demikian pula dengan jumlah serta tingkat suku bunga yang ditawarkan. Secara umum jenis-jenis kredit ditawarkan meliputi Kredit Investasi, Kredit Modal Kerja, Kredit Perdagangan, Kredit Produktif, Kredit Konsumtif, dan Kredit Profesi.

c) Memberikan jas-jasa bank lainnya (Service) Jasa-jasa bank lainnya merupakan kegiatan penunjang untuk mendukung kelancaran kegiatan menghimpun dan menyalurkan dana. Sekalipun sebagai kegiatan penunjang, kegiatan ini sangat memberikan keuntungan bagi bank dan nasabahnya, bahkan kegiatan ini memberikan kontribusi keuntungan yang tidak sedikit bagi bank, apalagi keuntungan dari spread based semakin mengecil, bahkan cenderung negatif spread (bunga simpanan lebih besar dari bunga kredit). Dalam praktiknya jasa-jasa bank yang ditawarkan yaitu kiriman uang (transfer), kliring, inkaso, Safe Deposit Box, Bank Card, Bank Garansi, L/C, Cek Wisata, dan lain sebagainya.

2. Kegiatan Bank Perkreditan Rakyat (BPR) Kegiatan Bank Perkreditan Rakyat pada dasarnya sama dengan kegiatan bank umum, hanya yang menjadi perbedaan adalah jumlah jasa bank yang dilakukan BPR jauh lebih sempit. Bank Perkreditan Rakyat dibatasi oleh beberapa persyaratan, sehingga tidak dapat berbuat seleluasa bank umum. Keterbatasan kegiatan Bank Perkreditan Rakyat juga dikaitkan dengan misi pendirian BPR itu sendiri. Dalam praktiknya kegiatan Bank Perkreditan Rakyat adalah sebagai berikut:

a) Menghimpun dana hanya dalam bentuk simpanan tabungan dan simpanan deposito.

b) Meyalurkan dana dalam bentuk Kredit Investasi, Kredit Modal Kerja, dan Kredit Perdagangan.

Karena keterbatasan yang dimiliki oleh BPR, maka ada beberapa larangan yang tidak boleh dilakukan BPR. Larangan ini meliputi hal-hal sebagai berikut:

a) Menerima simpanan giro

b) Mengikuti kliring

c) Melakukan kegiatan Valuta Asing

d) Melakukan kegiatan Perasuransian

Dari devinisi diatas dapat disimpulkan bahwa bank merupakan lembaga keuangan yang kegiatanyaa adalah:

1. menghimpum dana mastyarakat menghimpun dana dari masyarakat dalam bentuk simpanan, maksudnya dalam hal ini bank sebagai tempat menyimpan uang atau berinvestasi bagi masyarakat. Tujuan yaitu untuk keamanan uangnya, melakukan investasi dengan harapan memperoleh bunga dari hasil simpanannya dan untuk memudahkan melakukan transaksi pembayaran. Secara umum jeni simpanan giro, simpanan tabungan dan simpanan deposito

2. menyalurkan dana ke mayarakat

menyalurkan dana kemasyarakat maksudnya adalah bank memberi pinjaman kepada masyarakat yang mengajukan permohonan, dengan kata lain, bank menyediakan dana bagi masyarakat yang membutuhkannya. 
Jenis kredit yang biasa di berikan oleh hampir semua bank adalah seperti kredit investasi, kredit modal kerja dan kredit perdagangan.

3. Memberikan jasa-jasa bank lainnya

Jasa-jasa bank lainnya merupakan jasa pendukung dari kegiatan pokok bank seperti pengiriman uang dan penarikan uang.

Bank merupakan lembaga perantara keuangan antara masyarakat yang kelebihan dana dengan masyarakat yang kekurangan dana. Arus perputaran uang yang ada di bank dari masyarakat kembali ke masyarakat, dimanan bank sebagai perantara dapat dijelaskan sebagai berikut :

1. Nasabah (masyarakat) yang kelebihan dana menyimpan uangnya di bank dalam simpanan giro, tabungan atau deposito. Bagi bank dana yang disimpan oleh masyarakat adalah sama artinya dengan membeli dana. Dalam hal ini nasabah sebagai penyimpan dan bank sebagain penerima titipan simpanan. Nasabah dapat memilih sendirinuntuk menyimpan dana apakah dalam bentuk giro, tabungan atau deposito

2. Nasabah penyimpanan akan memperoleh balas jasa dari bank berupa bunga bagi bank konvesional dan bagi hasil bagi bank yang berdasarkan prinsip syariah. Besarnya jasa bunga dan bagi hasil tergantung dari besarnya dana yang di simpan dan factor lainnya

3. Kemudian oleh bank dana yang di simpan oleh nasabah di bank yang bersangkutan di salurkan kembali (dijual) kepada masyarakat yang kekurangn dana dalam bentuk pinjaman.

4. Bagi masyarakat yang memperoleh pinjaman atau kredit dari bank, diwajibkan kembali untuk mengembalikan pinjaman tersebut beserta bunga yang telah di tetapkan sesuai perjanjian antara bank dengan nasabah. Khusus bagi bank yang menggunakan prinsip syariah pengembalian disertai dengan sistem bagi hasil sesuai hokum islam

\section{b. Fungsi Bank}

Menurut Tridaru dan Santoso (2006:9) fungsi utama bank adalah sebagai berikut:

1. Agent Of Trust

Dasar utama kegiatan perbankan adalah trust atau kepercayaan, baik dalam hal penghimpun dana maupun penyaluran dana. Masyarakat akan mau menitipkan dananya di bank apabila dilandasi oleh unsur kepercayaan. Pihak bank percaya bahwa debitur akan mengelola dana pinjaman dengan baik, debitur akan mempunyai kemampuan untuk membayar pada saat jatuh tempo, dan juga bank akan percaya bahwa debitur mempunyai niat baik untuk mengembalikan pinjaman beserta kewajiban lainnya pada saat jatuh tempo.

2. Agent Of Development

Sektor dalam kegiatan perekonomian masyarakat yaitu sektor moneter dan sektor rill, tidak dapat dipisahkan. Kedua sektor tersebut berinteraksi saling mempengaruhi satu dengan yang lain sektor rill tidak akan berkinerja dengan baik apabila sektor moneter tidak bekerja dengan baik. Tugas bank sebagai penghimpun dana dan penyalur dana sangat 
diperlukan untuk kelancaran kegiatan perekonomian disektor rill. Kegiatan bank tersebut memungkinkan masyarakat melakukan investasi, distribusi, dan jga konsmsi barang dan jasa, mengingat semua kegiatan investasi, distribususi, dan konsumsi selalu berkaitan dengan penggunaan uang.Kelancaran kegiatan investasi, distribusi, dan konsmsi ini tidak lain adalah kegiatan pembangunan perekonomian masyarakat.

3. Agent Of Service

Disamping melakukan kegiatan penghimpunan dan penyaluran dana, bank juga memberikan penawaran jasa-jasa perbankan yang lain kepada masyarakat.

Jasa-jasa yang ditawarkan bank ini erat kaitannya dengan kegiatan perekonomian masyarakat secara umum. Jasa-jasa bank ini diantara lain dapat berupa pengiriman uang, jasa penitipan barang berharga, dan jasa pemberian jaminan jasa.

\section{c. Jasa jasa perbankan}

Jasa-jasa ini diberikan untuk mendukung kelancaran menghimpun dan menyalurkan dana, baik yang berhubungan langsung dengan kegiatan simpanan dan kredit maupun tidak langsung. Jasa perbankan lainya antaralain sebagai berikut:

1. Jas setoran seperti setoran pajak, setoran listrik, telepon, air, atau uang kuliah

2. Jasa pembayaran seperti pembayaran gaji, pensiun, atau hadiah

3. Jasa pengiriman uang (transfer)

Merupakan jasa kiriman uang antar bank baik bank yang sama maupun bank yang berbeda. Pengiriman uang juga dapat dilakukan dengan tujuan dalam kota, liar kota atau luar negeri. Khusu pengiriman keluar negeri harus melalui bank devisa

4. Jas penagihan (inkaso)

Merupakan penagihan wakaf (surat-surat berharga seperti cek, biliyet giro) antar bank yang berasal dari luar kota maupun luar negeri.

5. Kliring

Merupakan penagihan warkat (surat-surat berharga seperti cek, biliyet giro) yang berasal dari dalam kota termasuk transfer dalam kota antar bank.

6. Penjualan mata uang asing

7. Penyimpanan dokumen

8. Jasa cek wisata

Merupakan cek perjalan wisata yang bisa digunakan oleh para turis dan dibelanjakan di berbagai tempat

9. Kartu kredit

Merupakan jasa-jasa penerbitan kartu kredit yang dapat digunakan dalam berbagai transaksi dan penarikan uang di ATM.

10. Jasa-jasa yang ada di pasarmodal seperi pinjaman emisi dan perdagangan efek.

11. Jasa Letter of Credit(L/C) 
Merupakan jasa yang diberikan dalam rangka mendukung kegiatan atau transaksi ekspor dan impor

12. Bank garansi

Merupakan jaminan bank yang diberikan kepada nasabah dalam rangka membiayai suatu usaha

13. Bank Draft

Merupakan wesel yang dikeluarkan oleh bank kepada para nasabahnya.

\section{d. Jenis Jenis Bank}

Jenis Bank

Menurut Undang-Undang pokok perbankan Nomor 10 Tahun 1998, jenis perbankan menurut fungsinyaterdiri dari:

1. Bank Sentral

Bank sentral merupakan bank pusat. Bank ini mengatur sebagai kegiatan yang berkaitan dengan dunia perbankan dan dumia keuangan di suatu negara. Di indonesia fungsi bank sentral dipegang oleh Bank Indonesia. Fungsi Bank Indonesia disamping sebagagai bank sentral adalah mengatur perbankan disuatu negara dan sebagai tempat peminjam yang terakhir/

2. Bank Umum

Bank umum adalah bank yang melaksanakan kegiatan usaha secara konvensional dan atau berdasarkan prinsip syariah yang dalam kegiatannya memberikan jasa dalam lalu lintas pembayaran.Sifat jasa yang diberikan adalah umum, dalam arti dapat memberikan seluruh jasa perbankan yang ada.Begitu juga dengan wilayah operasinya dapat dilakukan diseluruh wilayah.

3. Bank Perkreditan Rakyat (BPR)

Bank Perkreditan Rakyat (BPR) adalah bank yang melaksanakan kegiatan usaha secara konvensional atau berdasarkan prinsip syariah yang dalam kegiatannya tidak memberikan jasa dalam lalulintas pembayaran, artinya disini kegiatan BPR jauh lebih sempit jika dibandingkan dengan kegiatan bank umum.

\section{e. Jenis-jenis kantor bank}

1. Kantor pusat

Merupakan kantor dimana semua kegiatan perencanaan sampai kepada pengawasan terdapat di kantor pusat. Kantor pusat tidak melakukan kegiatan oprasional sebagamana kantor bank lainya akan tetapi mengendaikan jalanya kebijaksanaan kantor pusat terhadap cabang cabangnya.

2. Kantor cabang penuh

Merupakan kantor cabang yang memberikan jasa bank paling lengkap. Dengan kata lain semua kegiatan perbankan ada di kantor cabang penuh

3. Kantor cabang pembatu

Merupakan kantor cabang yang berada di bawah kantor cabang penuh dan kegiatan jasa bank yang dilayani hanya sebagian dari kegiatan cabang penuh.

4. Kantor kas 
Merupakan kantor bank yang paling kecil dimana kegiatan hanya meliputi teller/kasir saja. Dengan kata lain hanya melakukan sebagian kecil dari kegiatan perbankan dan berada dibawah cabang pembantu atau cabng penuh .

\section{f. Sumber Dana Bank}

Sumber sumber dana bank adalah usaha bank dalam menghimpun dana untuk membiayai operasinya.

1. Dana Yang Bersumber Bank Itu Sendiri

Sumber dana bank ini merupakan sumber dana dari modal sendiri. Modal sendiri maksudnya adalah modal setoran dari para pemegang sahamnya. Apabila saham yang terdapat dalam portopel belum habis terjual, sedangkan kebutuhan dana masih perlu, maka pencariannya dapat dilakukan dengan menjual saham kepada pemegang saham yang lama. Akan tetapi, jika tujuan perusahaan untuk melakukan ekspansi, maka perusahaan dapat mengeluarkan saham baru tersebut di Pasar Modal. Disamping itu, pihak perbankan dapat pula menggunakan cadangancadangan laba yang belum digunakanKeuntungan dari sumber modal sendiri adalah tidak perlu membayar bunga yang relatif besar daripada jika meminjam ke lembaga lain.

2. Dana Yang Berasal Dari Masyarakat Luas

Sumber dana bank ini merupakan sumber terpenting bagi kegiatan operasi bank dan merupakan ukuran keberhasilan bank jika mampu membiayai operasinya dari sumber ini. Pencarian dana dari sumber ini relatif mudah jika dibandingkan dengan sumber lainnya dan pencarian sumber dana ini paling dominan, asal dapat memberikan bunga dan fasilitas menarik lainnya menarik dana dari sumber ini tidak terlalu sulit. Akan tetapi, pencarian sumber dana dari sumber ini relatif lebih mahal jika dibandingkan dari dana sendiri. Adapun sumber dana dari masyarakat luas dalam bentuk Simpanan giro merupakan dana murah bagi bank, karena bunga atau balas jasa yang dibayar paling murah jika dibandingkan dengan Simpanan tabungan dan Simpanan deposito, sedangkan Simpanan tabungan dan Simpanan deposito tersebut dana mahal, hal ini disebabkan bunga yang dibayar kepada pemegangnya relatif lebih tinggi, jika dibandingkan dengan jasa giro.

\section{g. Pengertian Nasabah}

Menurut undang-undang Nomor 10 Tahun 1998 Tentang Perbankan yang dimaksud nasabah adalah pihak yang menggunakan jasa bank nasabah terbagi dalam dua jenis yaitu:

1. Nasabah penyimpan

Nasabah Penyimpan adalah nasabah yang menempatkan dananya di bank dalam bentuk simpanan berdasarkan perjanjian bank dengan nasabah yang bersangkutan.

2. Nasabah debitur 
Nasabah debitur adalah nasabah yang memperoleh fasilitas kredit atau pembiayaan berdasarkan Prinsip Syariah atau yang dipersamakan dengan itu berdasarkan perjanjian bank dengan nasabah yang bersangkutan.

\section{h. Pengertian SLIK}

Peraturan Otoritas Jasa Keuangan Nomor 18 /POJK.03/2017 SLIK ( Sistem Layanan Informasi Keuangan) adalah sistem informasi yang dikelola oleh OJK untuk mendukung pelaksanaan tugas pengawasan dan layanan informasi di bidang keuangan.

\section{Metode Penelitian}

Metode penulisan yang digunakan dalam laporan tugas akhir ini adalah metode deskriftif yang merupakan suatu metode yang bertujuan untuk mengamati aspek aspek tertentu secara lebih spesifik untuk memperoleh data yang sesuai dengan masalah yang ada sesuai dengan tujuan praktek kerja lapangan, dimanan data / informasi yang diperoleh diproses lebih lanjut dengan dasar teori-teori yang telah dipelajari sehingga data tersebut dapat ditarik kesimpulan . menurut Whitney (1960) bahwa "metode deskriptif adalah pencarian fakta dengan interpretasi yang tepat. Penelitian deskriptif mempelajari masalah-masalah dalam masyarakat, serta tatacara yang berlaku selama masyarakat serta situasi-situasi tertentu, termasuk tentang hubungan kegiatan, sikap, pandangan,serta proses-proses yang sedang berlangsung dan pengaruh dari suatu fenomena"

\section{Hasil dan Pembahasan}

\section{a. Sejarah Singkat PT Bank Pembangunan Daerah Jawa Barat dan Banten}

Pendirian Bank Pembangunan Daerah Jawa Barat dilatarbelakangi oleh Peraturan Pemerintah Republik Indonesia Nomor 33/1960 tentang penentuan perusahaan di Indonesia milik Belanda yang dinasionalisasi. Salah satu perusahaan milik Belanda yang berkedudukan di Bandung yang dinasionalisasi adalah De Erste Nederlansche Indische Shareholding N.V., sebuah bank hipotek. Sebagai tindak lanjut atas diberlakukannya PP tersebut, Pemerintah Provinsi Jawa Barat dengan Akta Notaris Noezar nomor 152 tanggal 21 Maret 1961 dan nomor 184 tanggal 13 Mei 1961 dan dikukuhkan dengan Surat Keputusan Gubernur Provinsi Jawa Barat nomor 7/GKDH/BPD/61 tanggal 20 Mei 1961, mendirikan PD Bank Karya Pembangunan Daerah Jawa Barat dengan modal dasar untuk pertama kali berasal dari kas daerah sebesar Rp 2.500.000,00. Untuk menyempurnakan kedudukan hukum Bank Karya Pembangunan Daerah Jawa Barat, dikeluarkan Peraturan Daerah Provinsi Jawa Barat Nomor 11/PD-DPRD/72 tanggal 27 Juni 1972 tentang kedudukan hukum Bank Karya Pembangunan Daerah Jawa Barat sebagai perusahaan daerah yang bergerak di bidang perbankan. Selanjutnya melalui Peraturan Daerah Provinsi Jawa Barat Nomor 1/DP-040/PD/1978 tanggal 27 Juni 1978, nama PD Bank Karya Pembangunan Daerah Jawa Barat diubah menjadi Bank Pembangunan Daerah Jawa 
Barat. Pada tahun 1992, aktivitas Bank Pembangunan Daerah Jawa Barat ditingkatkan menjadi bank umum devisa berdasarkan Surat Keputusan Direksi Bank Indonesia Nomor 25/84/KEP/DIR tanggal 2 November 1992 serta berdasarkan Perda Nomor 11/1995 dengan sebutan Bank Jabar beserta logo baru. Dalam rangka mengikuti perkembangan perekonomian dan perbankan, maka berdasarkan Perda Nomor 22/1998 dan akta pendirian nomor 4 tanggal 8 April 1999 berikut akta perbaikan nomor 8 tanggal 15 April 1999 yang telah disahkan oleh Menteri Kehakiman Republik Indonesia tanggal 16 April 1999, bentuk hukum Bank Jabar diubah dari Perusahaan Daerah (PD) menjadi Perseroan Terbatas (PT). Untuk memenuhi permintaan masyarakat akan terselenggaranya jasa layanan perbankan yang berlandaskan syariah, maka sesuai dengan izin Bank Indonesia Nomor 2/18/DpG/DPIP tanggal 12 April 2000, terhitung sejak tanggal 15 April 2000, Bank Jabar menjadi BPD pertama di Indonesia yang menjalankan sistem perbankan ganda dengan memberikan layanan perbankan secara konvensional dan syariah.

Berdasarkan hasil rapat umum pemegang saham luar biasa (RUPS-LB) PT Bank Pembangunan Daerah Jawa Barat dan Banten tanggal 3 Juli 2007 di bogor, sesuai dengn surat keputusan Gubernur Bank Indonesia No.9/63/KEP.GBI/2007 tanggal 26 November 2007 tentang perubahan izin usaha atas nama PT Bank Pembangunan Daerah Jawa Barat dan Banten serta SK Direksi NOMOR 1065/SK/DIR-PPN/2007 tanggal 29 November 2007 maka nama perseroan berubah menjadi PT Bank Pembangunan Daerah Jawa Barat dan Banten dengan sebutan (call name) Bank Jabar Banten. Berdasarakan hasil rapat umum pemegangsaham luar biasa (RUPSLB) PT Bank Pembangunan Daerah Jawa Barat dan Banten Nomor 26 tanggal 21 April 2010, sesuai dengan surat Bank Indonesia No.12/78/APBU/BD tnggal 30 Juni 2010 perihal rencana perubahan Logo serta surat keputusan direksi Nomor 1337/SK/DIR-PPN/ 2010 tanggal 5 Juli 2010, maka perseroan telah berganti sebutan menjadi Bank BJB. Pada bulan Juli 2010, Bank BJB menjadi BPD pertama di Indonesia yang melantai saham di Bursa Efek Indonesia. Sebagai Bank yang sedang berkembang, Bank Jabar Banten (BJB) terus berusaha meningkatkan kinerja dan keberhasilan yang telah dicapai sebelumnya guna mendukung visi Bank BJB yaitu, "Menjadi sepuluh Bank Terbesar di Indonesia dan Berkinerja Baik". Misinya adalah"Penggerak dan pendorong laju perekonomian di daerah, melaksanakan penyimpanan uang daerah dan sebagai salah satu sumber pendapatan asli daerah" . Sebagai salah satu kelengkapan otonomi daerah, PT. Bank Pembangunan Jawa Barat Dan Banten mempunyai fungsi sebagai berikut : penggerk dari pendorong laju perokomonian di daerah, sebagai pemegang kas daerah dan salah satu sumber pendapatan asli daerah. Sebagai pernyataan dari budaya perusahaan di atas, kami memiliki pilar-pilar budaya perusahaan yang merupakan penjabaran pilar utama di atas sebagai acuan pokok bagaimana perilaku seluruh jajaran PT. Bank Pembangunan Jawa Barat Dan Banten dalam melakukan pengelolaan bisnisnya.

Dalam rangka mendukung pencapaian visi dan misi PT. Bank Pembangunan Jawa Barat Dan Banten menjadi 10 bank terbesar dan berkinrja baik di Indonesia, PT. Bank Pembangunan Jawa Barat Dan Banten telah melakukan beberapa perubahan, salah satunyaperubahan. Budaya perusahaan tersebut mencerminkan semangat PT. Bank Pembangunan Jawa Barat Dan Banten dalam menghadapi persaingan perbankan yang semakin ketat dan dinamis.Pernyataan budaya perusahaan PT. 
Bank Pembangunan Jawa Barat Dan Banten adalah "mitra usaha menuju sejahtera" sebagaimana pernyataan dari budaya perusahaan yang tercantum di atas, PT. Bank Pembangunan Jawa Barat Dan Banten memiliki pilar-pilar budaya perusahaan yang merupakan penjabaran atas pilar utama di atas sebagai acuan pokok bagaimana perilaku seluruh jajaran PT. Bank Pembangunan Jawa Barat Dan Banten dalam melakukan pengelolaan bisnisnya. "Pilar pilar budaya perusahaan PT. Bank Pembangunan Jawa Barat Dan Banten"

\section{b. SLIK (sistem layanan informasi keuangan) pada PT. Bank Jabar Banten Kantor Cabang pembantu Jalancagak}

SLIK merupakan pengganti SID atau BI CHEKING yang dulu di kelola Bank Indonesia. Terbitnya UU No. 21 Tahun 2011 tentang OJK mengharuskan Bank Indonesia (BI) mengalihkan layanan SID ke Otoritas Jasa Keuangan (OJK). Dalam UU tersebut, OJK bersama BI punya wewenang atas pengaturan sistem informasi debitur demi terjaganya kesehatan bank. Peran BI (Bank Indonesia) dalam pengelolaan, pengaturan, dan pengembangan sistem informasi antar bank secara bertahap diambilalih OJK mulai dari 31 Desember 2013 hingga 31 Desember 2017. Lamanya mengembangkan sistem aplikasi SLIK jadi kendala kenapa SLIK tidak langsung diterapkan. Hingga akhirnya per 1 Januari 2018, SLIK benar-benar digunakan secara luas. SLIK adalah sistem informasi yang dikelola oleh Otoritas Jasa Keuangan $(\mathrm{OJK})$ untuk mendukung pelaksanaan tugas pengawasan dan layanan informasi di bidang keuangan. Salah satu layanan informasi yang akan diberikan oleh OJK melalui SLIK adalah layanan Informasi Debitur. Informasi Debitur adalah informasi mengenai Debitur, Fasilitas Penyediaan Dana yang diterima

Debitur, dan informasi terkait lain yang disajikan berdasarkan Laporan Debitur yang diterima oleh OJK dari Pelapor melalui aplikasi SLIK.

1. Aplikasi SLIK

SLIK terdiri dari 3 (tiga) aplikasi yaitu aplikasi SLIK Reporting, aplikasi SLIK Web, dan aplikasi iDeb Viewer.

2. Aplikasi SLIK Reporting adalah aplikasi yang dipasang pada perangkat komputer Pelapor. Fungsi aplikasi SLIK Reporting antara lain untuk validasi data, enkripsi, kompresi, dan pembentukan file laporan yang siap dikirim ke peladen (server) OJK. Selain itu, pada aplikasi SLIK Reporting juga terdapat fungsi untuk pengiriman Laporan Debitur langsung ke peladen (server) OJK melalui File Transfer Protocol (FTP).

Gambar 1

Tampilan Aplikasi SLIK Reporting

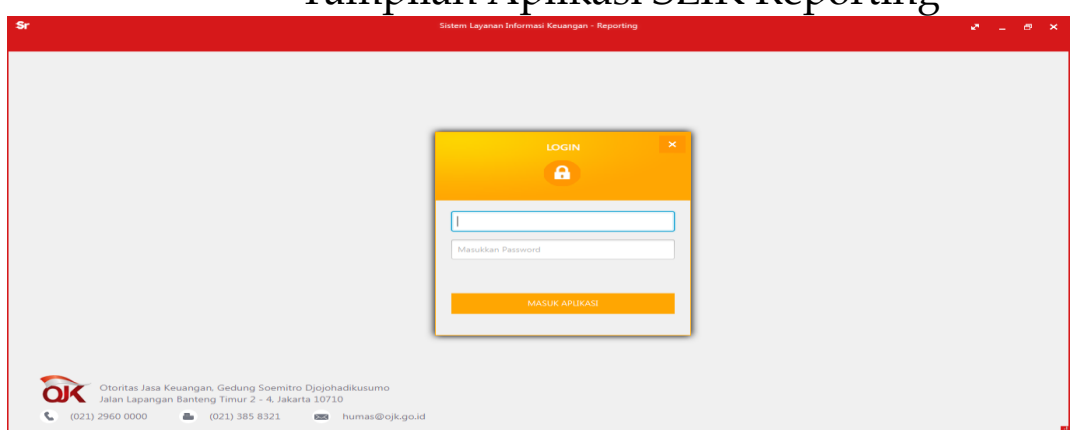


3. Aplikasi SLIK Web

adalah aplikasi yang dipasang di OJK dan diakses oleh Pelapor menggunakan Web browser melalui jaringan komunikasi data yang ditetapkan oleh OJK. Aplikasi SLIK Web memiliki fungsi antara lain untuk mengunggah (upload) file LaporanDebitur sebagai alternatif pengiriman laporan, pemantauan laporan, permintaan Informasi Debitur, pemantauan permintaan Informasi Debitur, koreksi data secara daring (online), pengelolaan pengguna, dan pemantauan aktivitas pengguna.

\section{Gambar 2}

Tampilan Aplikasi SLIK Web

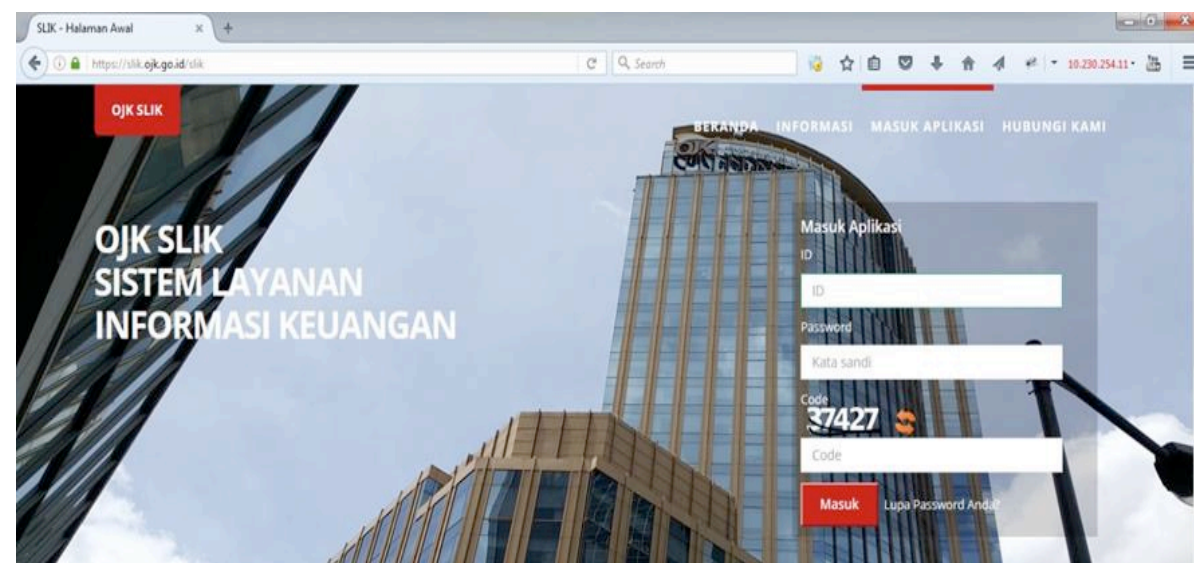

4. Aplikasi iDeb Viewer adalah aplikasi yang dipasang di komputer Pelapor untuk menampilkan hasil permintaan Informasi Debitur dari aplikasi SLIK Web.

Gambar 3

Tampilan Aplikasi Ideb Viewer

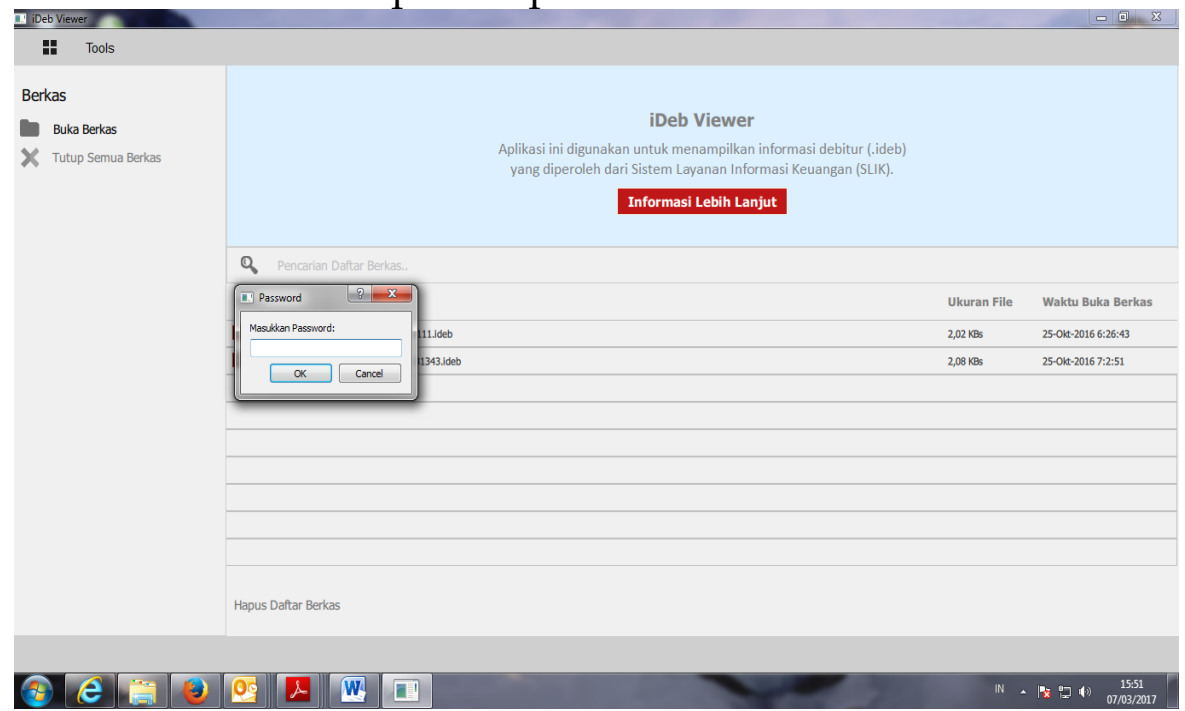




\section{c. Bagaimana peranan SLIK (sistem layanan informasi keuangan) pada PT. Bank Jabar Banten Kantor Cabang pembantu Jalancagak}

peranan SLIK (sistem layanan informasi keuangan) pada PT. Bank Jabar Banten Kantor Cabang pembantu Jalancagak adalah sebagai alat untuk mempercepat analisis pemberian kredit karena data yang tersedia di SLIK berupa informasi debitur

Informasi Debitur adalah informasi mengenai Debitur, Fasilitas Penyediaan Dana yang diterima Debitur, beserta informasi terkait lain yang dikompilasi berdasarkan Laporan Debitur yang diterima oleh OJK dari Pelapor SLIK di seluruh Indonesia.

Informasi Debitur adalah informasi yang bersifat pribadi dan rahasia sehingga Pelapor harus menjaga keamanan Informasi Debitur. Pelapor hanya dapat menggunakan Informasi Debitur untuk:

1. Mendukung kelancaran proses pemberian Fasilitas Penyediaan Dana;

2. Menerapkan manajemen risiko; dan/atau

3. Mengidentifikasi kualitas Debitur dalam rangka pemenuhan ketentuan OJK atau permintaan dari pihak lain yang berwenang.

Permintaan Informasi Debitur kepada OJK hanya dapat dilakukan secara daring (online) oleh pegawai pelaksana dan/atau pejabat yang telah diberikan akses oleh administrator SLIK Web masing-masing Pelapor untuk melakukan permintaan Informasi Debitur pada aplikasi SLIK Web. Permintaan Informasi Debitur melalui aplikasi SLIK Web dapat dilakukan secara interaktif atau secara batch.

1. Permintaan Informasi Debitur Secara Interaktif

Permintaan Informasi Debitur secara interaktif dilakukan dengan mengisi formulir permintaan Informasi Debitur pada aplikasi SLIK Web. Informasi yang tidak dapat dikosongkan pada formulir permintaan Informasi Debitur secara interaktif adalah:

a) Kode Referensi Pengguna

Kode ini digunakan sebagai referensi atas setiap permintaan Informasi

Debitur. Kode ini harus unik untuk setiap permintaan Informasi Debitur.

b) Tujuan Permintaan Informasi Debitur

Pelapor dapat mengisi tujuan permintaan Informasi Debitur dengan pilihan sebagai berikut:

Tabel 1

Tujuan Permintaan Informasi Debitur

\begin{tabular}{|l|l|}
\hline \multicolumn{1}{|c|}{ Tujuan Permintaan Informasi Debitur } & Kode \\
\hline Penilaian calon Debitur & 01 \\
\hline Penerapan one obligor concept & 02 \\
\hline Monitoring Debitur existing & 03 \\
\hline Melayani permintaan Debitur & 04 \\
\hline
\end{tabular}




\begin{tabular}{|l|l|}
\hline \multicolumn{1}{|c|}{ Tujuan Permintaan Informasi Debitur } & Kode \\
\hline Dalam rangka pelaksanaan audit & 05 \\
\hline Penanganan pengaduan Debitur & 06 \\
\hline Penilaian karyawan atau calon karyawan & 07 \\
\hline Penilaian calon rekanan & 08 \\
\hline
\end{tabular}

c) Kata Kunci Pencarian

Terdapat 2 (dua) pilihan pencarian Informasi Debitur, yaitu pencarian berdasarkan nomor identitas atau pencarian menggunakan kombinasi data. Kata kunci yang dapat digunakan dalam pencarian Informasi Debitur adalah:

Tabel 2

Pencarian Data Informasi Debitur Menggunakan Nomor Identitas dan Kombinasi Data

\begin{tabular}{|c|c|c|c|}
\hline Jenis Debitur & $\begin{array}{c}\text { Pilihan } \\
\text { Pencarian }\end{array}$ & Kata Kunci & Keterangan \\
\hline \multirow[t]{6}{*}{$\begin{array}{l}\text { Debitur } \\
\text { Perseorangan }\end{array}$} & $\begin{array}{l}\text { Pencarian } \\
\text { Berdasarkan } \\
\text { Nomor } \\
\text { Identitas }\end{array}$ & $\begin{array}{l}\text { Nomor } \\
\text { Identitas } \\
\text { Debitur (NIK } \\
\text { atau Nomor } \\
\text { Paspor) }\end{array}$ & $\begin{array}{l}\text { Tidak dapat } \\
\text { Dikosongkan }\end{array}$ \\
\hline & \multirow[t]{5}{*}{$\begin{array}{l}\text { Pencarian } \\
\text { Berdasarkan } \\
\text { Kombinasi } \\
\text { Data }\end{array}$} & Nama Debitur & $\begin{array}{l}\text { Tidak dapat } \\
\text { dikosongkan, } \\
\text { dapat dipilih } \\
\text { Pencarian } \\
\text { Berdasarkan } \\
\text { Kesamaan } \\
\text { Atau } \\
\text { Kemiripan }\end{array}$ \\
\hline & & Tanggal Lahir & $\begin{array}{l}\text { Tidak dapat } \\
\text { Dikosongkan }\end{array}$ \\
\hline & & Jenis Kelamin & $\begin{array}{l}\text { Tidak dapat } \\
\text { Dikosongkan }\end{array}$ \\
\hline & & Tempat Lahir & Opsional \\
\hline & & NPWP & Opsional \\
\hline \begin{tabular}{l|} 
Debitur \\
Badan Usaha
\end{tabular} & $\begin{array}{l}\text { Pencarian } \\
\text { Berdasarkan } \\
\text { Nomor } \\
\text { Identitas }\end{array}$ & $\begin{array}{l}\text { Nomor } \\
\text { Identitas } \\
\text { Debitur } \\
\text { (NPWP, }\end{array}$ & $\begin{array}{l}\text { Tidak dapat } \\
\text { Dikosongkan }\end{array}$ \\
\hline
\end{tabular}




\begin{tabular}{|c|c|c|}
\hline & $\begin{array}{l}\text { TaxID/nomor } \\
\text { sejenis) }\end{array}$ & \\
\hline \multirow[t]{3}{*}{$\begin{array}{l}\text { Pencarian } \\
\text { Berdasarkan } \\
\text { Kombinasi } \\
\text { Data }\end{array}$} & $\begin{array}{l}\text { Nama Badan } \\
\text { Usaha }\end{array}$ & $\begin{array}{l}\text { Tidak dapat } \\
\text { dikosongkan, } \\
\text { dapat dipilih } \\
\text { Pencarian } \\
\text { Berdasarkan } \\
\text { Kesamaan } \\
\text { Atau } \\
\text { Kemiripan } \\
\end{array}$ \\
\hline & $\begin{array}{l}\text { Tanggal } \\
\text { Pendirian }\end{array}$ & $\begin{array}{l}\text { Tidak dapat } \\
\text { Dikosongkan }\end{array}$ \\
\hline & $\begin{array}{l}\text { Tempat } \\
\text { Pendirian }\end{array}$ & Opsional \\
\hline
\end{tabular}

d) Kode CAPTCHA

Kode yang harus diisi untuk tujuan keamanan sistem.

Setelah mengisi formulir permintaan Informasi Debitur secara lengkap, petugas Pelapor dapat memulai pencarian. Selanjutnya, petugas Pelapor harus meneliti kembali identitas Debitur yang diminta dan memilih Debitur yang akan diproses lebih lanjut berdasarkan daftar Debitur hasil pencarian oleh sistem. Perlu dipahami bahwa tidak semua hasil pencarian merujuk pada 1 (satu) Debitur tertentu. Hal ini sangat tergantung pada kondisi data Debitur yang diperoleh oleh OJK dari seluruh Pelapor SLIK di Indonesia.

Informasi tentang calon debitur merupakan faktor penting dalam menentukan tingkat risiko yang bakal dihadapi bank dalam memberikan fasilitas kredit, Informasi debitur tersebut dapat diakses dan dipergunakan sebagai informasi pendukung dalam melakukan analisa kredit. Begitu pula bagi PT. Bank Pembangunan Daerah Jawa Barat dan Banten,Tbk yang kegiatan utamanya penghimpun dana dan menyalurkan kredit kepada masyarakat, Dalam menganalisa kredit sangat membutuhkan informasi debitur.

SLIK juga dibentuk sebagai wadah informasi pembiayaan dan perkreditan antar lembaga di bidang keuangan, SLIK akan merekam seluruh data yang bermanfaat bagi bank atau pengelola informasi perkreditan, dengan informasi debitur yang dihasilkan oleh SLIK PT. Bank Pembangunan Jawa Barat Dan Banten Kantor Cabang Pembantu Jalancagak bisa memutuskan apakah calon debitur layak diberikan pinjaman atau tidak.

\section{Kesimpulan}

Untuk peranan SLIK (sistem layanan informasi keuangan) pada Bank Pembangunan Jawa Barat Dan Banten Kantor Cabang Pembantu Jalancagak yaitu sebagai salah satu alat berbentuk aplikasi yang di luncurkan oleh Otoritas Jasa Keuangan atau biasa di sebut OJK untuk menyeleksi calon debitur dan sangat 
membantu akan peneyeleksian calon debitur karena SLIK memberikan informasi mengenai calon debitur tentang informasi historis debitur memuat data yang kumplit bagi pihak bank untuk pengambilan keputusan

Peranan SLIK atau sistem layanan informasi keuangan yang di luncurkn Otoritas Jasa Keuangan sangat berguna bagi pihak kreditur yang dalam hal ini adalah Bank BJB KCP Jalancagak tetapi Pihak kreditur harus cerdas dan cermat dalam mengolah data calon nasabah saat mengajukan permohonan kredit agar tidak terjadi kesalahan, karena bisa saja saat mengajukan permohonan kredit calon nasabah memalsukan data identitas diri yang dipakai sebagai syarat untuk pengajuan kredit sehingga nanti akan terjadi masalah seperti halnya kredit macet dan nantinya akan berimbas kepada kesejahteraan karyawan PT. Bank Pembangunan Jawa Barat Dan Banten.

\section{Referensi}

Kasmir, Dasar-Dasar Perbankan .Jakarta: PT. Raja Grafindo Perseda, 2014

Kasmir. Analisis Laporan Keuangan. Jakarta: PT Raja Grafindo Persada 2010.

silalahi Ulber, Studi tentang Ilmu Administrasi: Konsep, Teori dan Dimensi Bandung: Sinar Baru Algensindo 1989

F.L,Whitney.The Elements of Resert.Asian Eds. Osaka: .1960

Umar, Husein.. Metode Penelitian Untuk Skripsi dan Tesis Bisnis, Edisi Baru, Cetakan Keempat, Jakarta: Raja Grafindo Persada. 2004

Silalahi, Ulber. Asas-asas Manajemen. Bandung : Reflika Aditama 2011.

Dendawijaya, Lukman, Manajemen Perbankan, Jakarta. Ghalia Indonesia, 2009.

Siagian, Sondang, P. Organisasi dan Prilaku Organisasi. Jakarta: Mas Agung. 2007.

Budisantoso, Totok dan Sigit Triandaru. Bank dan Lembaga Keuangan Lain. Edisi 2: Jakarta.. Salemba Empat 2006

Gie,The Liang, Administrasi Perkantoran. Yogyakarta,,Modern Liberty 2009.

Mulyana Rahman dan Enceng,Administrasi Keuangan ed.:2 Tangerang Selatan:Universitas Terbuka,2015

Undang-Undang Republik Indonesia No.10 Tahun 1998 tentang perubahan Undang Undang No. 7 Tahun 1992 tentang perbankan

Surat Edaran Otoritas Jasa Keuangan Nomor 50 /SEOJK.03/2017 Tentang Pelaporan Dan Permintaan Informasi Debitur Melalui Sistem Layanan Informasi Keuangan 
https://www.cermati.com/artikel/slik-ojk-layanan-pengganti-bi-checkingbagaimanakah-cara-ceknya

https://www.ojk.go.id/id/kanal/perbankan/Pages/Sistem-Layanan-InformasiKeuangan-SLIK.aspx

www.bankbjb.co.id 